Brit. J. vener. Dis. (1963), 39, 242.

\title{
MEDICO-SOCIAL ASPECTS OF THE UNDIMINISHED INCIDENCE OF URETHRITIS IN FRANCE*
}

\author{
BY
}

\section{A. SIBOULET}

Chef de Consultation a l'Hôpital St. Louis, Paris

Despite the advances of therapy and technical research, and despite modern improvements in social and economic conditions, venereal diseases are still to be reckoned with, and an important part of the world's population continues to be infected with them. In France and elsewhere, syphilis has been steadily increasing since 1954, gonococcal urethritis is becoming more frequent, non-gonococcal urethritis (N.G.U.) now studied together with the venereal diseases, is increasing to an alarming extent, and minor venereal infections such as balanitis and venereal warts are also seen more frequently. Our clinic comprises the largest hospital practice for urethritis in France, in the department of Prof. Kuss at the Hôpital St. Louis in Paris, where the number of patients was 22,989 in 1962.

\section{Present Survey}

Statistics show that in 1962 the rate of gonococcal urethritis per 10,000 inhabitants was higher than in 1951. In my own experience, of 25,438 new patients in 1961, 3,519 had gonorrhoea, and of 22,989 new patients in 1962, 3,498 had gonorrhoea. In all doubtful cases a culture was carried out to determine the aetiology of the infection. Recently, of 4,978 male cases of urethritis, $14 \cdot 76$ per cent. had gonorrhoea and $65 \cdot 21$ per cent. had N.G.U. Table I shows the types of infection in 1,000 male cases of urethritis.

Trichomonas vaginalis is found in over 10 per cent. of men with N.G.U. and in over 20 per cent. of females with urethro-genital disorders. Routine cultures reveal an increasing number of trichomonal infections.

Fungi can be transmitted through sexual intercourse, and C. albicans and monilia are often found, either alone or with Trichomonas vaginalis.

Urethro-genital syndromes with a virus aetiology (less than 4 per cent. of abacterial urethritis) are increasing, and since 1950 the numbers of cases of the urethro-conjunctivo-synovial Reiter's syndrome have been steadily rising. French army medical officers (Roumagnac, Tenard, Pernod, Mémin,

\footnotetext{
* Paper read at M.S.S.V.D. meeting in Copenhagen, June 7, 1963.
}

TABLE I

AETIOLOGICAL SURVEY OF 1,000 MALE CASES OF URETHRITIS

\begin{tabular}{|c|c|c|c|c|c|c|}
\hline \multirow{2}{*}{\multicolumn{5}{|c|}{ Aetiology }} & \multicolumn{2}{|c|}{ Cases } \\
\hline & & & & & \multirow{2}{*}{$\frac{\text { Number }}{192}$} & \multirow{2}{*}{$\frac{\text { Per cent. }}{19 \cdot 2}$} \\
\hline Gonorrhoea & $\cdots$ & . & $\cdots$ & $\cdots$ & & \\
\hline Bacteria & $\cdots$ & . & $\cdots$ & $\cdots$ & 181 & $18 \cdot 1$ \\
\hline Fungus . . & $\cdots$ & $\cdots$ & $\cdots$ & $\cdots$ & 143 & $14 \cdot 3$ \\
\hline \multicolumn{3}{|c|}{ Trichomonas vaginalis } & . & $\ldots$ & 142 & $14 \cdot 2$ \\
\hline \multicolumn{3}{|c|}{ Associated " $L$ " organisms } & $\ldots$ & $\ldots$ & 84 & $8 \cdot 4$ \\
\hline \multicolumn{3}{|c|}{$T$. vaginalis $+C$. albicans } & . & . & 63 & $6 \cdot 3$ \\
\hline Virus $\quad \ldots$ & $\cdots$ & $\cdots$ & $\cdots$ & $\cdots$ & 23 & $2 \cdot 3$ \\
\hline Bilharzia & $\cdots$ & $\cdots$ & $\cdots$ & $\cdots$ & 9 & $0 \cdot 9$ \\
\hline Not Known & $\ldots$ & . & . & .. & 163 & $16 \cdot 3$ \\
\hline
\end{tabular}

Masbenard, Darbon, Lacroux, Ougier) observe several hundred cases every year, among which a number seem to have a virus aetiology. Increasingly frequent, too, are the various minor venereal infections, especially balanitis, which very often accompany urethritis.

\section{Clinical and Social Aspects}

As antibiotics continue to give good results in most individuals with infectious urethritis, one may ask why this increase is taking place. The main clinical and social features (in France at least) include:

(1) The steady traffic between the mother-country, North Africa, and Central Africa.

(2) The shifting masses of North African workers in France. Quite a number of them go on holiday to their native country every year, and in some North African communities over 40 per cent. come back with urethritis; 10 to 33 per cent. of the North Africans employed in France have positive serological tests.

(3) The fact that a good proportion of the sexuallymature male population did their military service in North Africa from 1950 up to 1962.

(4) The return home of many civil servants from IndoChina, and from Africa; the increasing number 
of foreign workers in France and of French engineers going out to work in Africa.

(5) Fast air journeys from one country to another. Recent epidemiological inquiries have demonstrated the dangers of infection, especially in Paris and on the French Riviera.

(6) Some believe that there has been a change in sexual behaviour which encourages greater freedom of intercourse between young people.

(7) The propagation of both urethritis and syphilis is mostly due to the new type of amateur or clandestine prostitute.

(8) The rapid increase of cases in homosexuals involving gonorrhoea, N.G.U., and syphilis.

In addition to these factors there have been technical advances in diagnosis; cultures of gonococcus, $T$. vaginalis, and fungi are becoming routine practice, and cultures of virus inclusions have also recently been introduced, together with the immunofluorescence technique, to demonstrate the formation of virus antigens in patients with urethritis. Furthermore, the antibiotics, by quickly curing patients, enable re-infection to occur all the more easily.

With careful selection of the right antibiotic, the "one-minute" treatment prescribed by us in co-operation with Dr. P. Durel gives good results in 95 per cent. of cases of acute gonorrhoea (Table II).

TABLE II

"ONE-MINUTE" TREATMENT OF GONORRHOEA (Single oral dose-2.5 g.)

\begin{tabular}{|c|c|c|c|c|c|}
\hline \multirow{2}{*}{\multicolumn{3}{|c|}{ Drug }} & \multirow[t]{2}{*}{$\begin{array}{l}\text { No. of } \\
\text { Patients }\end{array}$} & \multicolumn{2}{|c|}{$\begin{array}{c}\text { Results } \\
\text { (after two provocative } \\
\text { tests) }\end{array}$} \\
\hline & & & & Cure & Failure \\
\hline \multicolumn{2}{|c|}{ Spiramycin (Rovamycin) } & $\cdots$ & 3,751 & 3,677 & 74 \\
\hline Thiophenicol . & $\cdots$ & $\cdots$ & 179 & 177 & 2 \\
\hline Cyclomycetin . & $\cdots$ & $\cdots$ & 157 & 153 & 4 \\
\hline \multicolumn{2}{|c|}{ Pristignamycin (Pyostacin) } & $\cdots$ & 127 & 120 & 7 \\
\hline \multicolumn{3}{|c|}{$\begin{array}{cccc}\text { Mexocin (Dimethyl Chlortetra- } \\
\text { cycline) } & \ldots & \ldots & \ldots\end{array}$} & 73 & 71 & 2 \\
\hline Total $\ldots$ & $\cdots$ & $\cdots$ & 4,287 & 4,198 & 89 \\
\hline
\end{tabular}

In spite of the efficiency of most antibiotics against the gonococcus, the incidence of gonorrhoea goes up every year, chiefly because it is so difficult to find and cure the contacts. The surprising disproportion between the number of men and women treated is a most convincing proof of this; in 1962 , at the Hôpital St. Louis, we treated 3,244 men with gonorrhoea, but only 254 women. There is also in France the deeply-rooted idea that venereal diseases constitute only a minor problem, so that in many cases, early bacteriological diagnosis is omitted. Too often, some antibiotic is prescribed at random and this may result in failure or may perhaps mask a syphilitic infection. Needless to say we are deeply concerned by this problem. At the Hopital St. Louis there were only 465 cases of early syphilis in 1958 compared with 1,293 in 1962, and this figure is expected to rise in 1963. For this reason, whatever the pattern of urethritis may be, we insist upon a serological test for syphilis on the first day, and again at 30 and 60 days after the end of treatment. Such precautions we deem indispensable in the face of the growing frequency of clinically unusual features of syphilis.

\section{Summary}

Although antibiotics have altered the prognosis of urethritis by suppressing most of the complications, and despite the efficiency of treatment in the individual, a remarkable increase in the incidence of urethritis has occurred in France. This increase may in fact be greater than that shown by the official statistics. At only one clinic (Hopital St. Louis) the author found 3,498 cases of gonorrhoea $(3,244$ males and 254 females) among 22,989 patients in 1962. The most important causes are the unsupervized semi-prostitutes and amateurs, the increase in homosexuality, the indiscriminate prescribing of antibiotics, and the difficulty of tracing infected women.

\section{Persistance des blennorragies en France RÉSUMÉ}

Malgré l'efficacité individuelle des antibiotiques, les statistiques prouvent en France une augmentation du nombre des urétrites gonococciques ou non-gonococciques. A sa seule consultation de l'Hôpital Saint-Louis, l'auteur releva en 1962 sur 22.989 consultants, 3.498 cas de gonococcie (3.244 hommes, 254 femmes). Des divers facteurs medico-sociaux énumérés, retenons: le rôle de la semi-prostitution et de la prostitution clandestine; l'augmentation du nombre de cas dus à l'homosexualité; le fait de donner trop souvent des antibiotiques sans diagnostic précis préalable; et surtout la difficulté de trouver et de traiter les contaminatrices. 